\title{
Implementing the State Duty to Consult in Land and Resource Decisions: Perspectives from Sami Communities and Swedish State Officials
}

\author{
Rasmus Kløcker Larsen` \\ Stockholm Environment Institute \\ Kaisa Raitio \\ Swedish University of Agricultural Sciences
}

\begin{abstract}
The duty of states to consult indigenous communities is a well-established legal principle, but its implications for practice remain uncertain. Sweden is finding itself at a particularly critical juncture as it prepares to legislate a duty to consult the Sami people in line with its international obligations. This paper explores the ability of Swedish state actors to implement the duty to consult, based on lessons from an already existing duty set out in Swedish minority law, namely to ensure the effective participation of minorities in land and resource decisions. Presenting novel empirical material on the views of Sami communities and state officials in ministries and agencies, we demonstrate the existence of considerable implementation gaps linked to practice, sectoral legislation, and political discourse. We argue that if state duties are to promote the intended intercultural reconciliation, then new measures are needed to ensure enforcement, e.g. via mechanisms of appeal and rules of nullification. In addition, sectoral resource regulations should be amended to refer to the duties set out in minority law and/or a potential new bill on consultation duty in a consistent manner. In the near-term, the state should ensure that Sami communities are adequately resourced to engage in consultation and should invest in state authorities' own ability to implement, i.e. through competence development, staffing, intersectoral coordination, and independent evaluation. Much could also be gained if state agencies and Sami communities worked together to develop detailed consultation routines for relevant resource sectors.
\end{abstract}

Keywords: consultation; participation; natural resources; indigenous rights; Sami rights; Swedish law; minority law

Responsible Editor: Øyvind Ravna, UiT The Arctic University of Norway, Tromsø, Norway

Received: July 2018; Accepted: December 2018; Published: January 2019

^Correspondence to: Rasmus Kløcker Larsen, email: rasmus.klocker.larsen@sei.org

(C) 2019 Rasmus Kløcker Larsen \& Kaisa Raitio. This is an Open Access article distributed under the terms of the Creative Commons Attribution-NonCommercial 4.0 International License (https://creativecommons.org/licenses/by-nc/4.0/), allowing third parties to share their work (copy, distribute, transmit) and to adapt it, under the condition that the authors are given credit, that the work is not used for commercial purposes, and that in the event of reuse or distribution, the terms of this license are made clear.

Citation: Rasmus Kløcker Larsen \& Kaisa Raitio. "Implementing the state duty to consult in land and resource decisions:

Perspectives from Sami communities and Swedish state officials" Arctic Review on Law and Politics, Vol. 10, 2019 , pp. 4-23. http://dx.doi.org/10.23865/arctic.v10.1323 


\section{Introduction}

One of the cornerstones of international indigenous rights law established in recent decades is the principle of the duty to consult, i.e. the duty of states to consult indigenous communities before planning resource developments on traditional lands. Several international conventions and declarations outline what is variously expressed as procedural or participatory rights, including: the United Nations Declaration on the Rights of Indigenous Peoples (UNDRIP), the International Labor Organization's Convention 169 on Indigenous and Tribal Peoples in Independent Countries, and the UN Convention on the Elimination of All Forms of Racial Discrimination. ${ }^{1}$ Such procedural or participatory rights are important, first and foremost, since they function as a means of ensuring indigenous influence in decision making and giving effect to their substantive rights to land, resources and culture. ${ }^{2}$ While UNDRIP is not binding and ILO 169 remains unratified by many states, they influence the interpretation of older, binding conventions such as the International Covenant on Civil and Political Rights, which recognize the right of indigenous peoples to practice their culture, and highlight the duty to consult as a central means to protect this right.

A central question in the enactment of the duty to consult regards the degree of influence affected indigenous communities should have on state decisions, i.e. the relationship between "consultation" and "consent". To be sure, debate among legal scholars continues on this matter. ${ }^{3}$ One common interpretation is that the state must genuinely seek but not necessarily reach agreement with indigenous communities prior to resource developments. ${ }^{4}$ However, in light of the conclusions of human rights monitoring bodies, indigenous peoples have a right to give or withhold consent, with a qualified right to veto in cases where decisions on large-scale projects may significantly jeopardize their livelihoods. ${ }^{5}$ How this duty should be implemented concretely in decision-making linked to land and resources will vary between jurisdictions, since practice is not, and cannot be, specified in international law. Past research has aptly shown how, globally, the concrete implication of the duty of states to consult indigenous communities has been interpreted and applied in highly different ways by different countries. In consequence, some consultations are heralded as successes of proactive relationship-building while other consultations are seen as dominated by business interests. ${ }^{6}$ At worst, governments and developers may employ token consultations only to curtail indigenous protests, whereby communities are further disempowered. ${ }^{7}$

To enhance clarity on the general meaning of the duty to consult, one interpretation advanced by legal scholars is based on the so-called sliding scale theory in relation to indigenous self-determination, namely that "the more important the issue to the indigenous people's culture, society and way of life, the greater influence the people should be allowed to exercise over the decision-making process". ${ }^{8}$ Such a view underpins efforts to clarify consultation procedures. For instance, in parts of Canada, such as British Columbia, the provincial government approaches the determination 


\section{Rasmus Kløcker Larsen E Kaisa Raitio}

of the extent of engagement with indigenous communities proportionate to i) the strength of indigenous rights (e.g. to culture or to land and resources) and ii) the severity of the expected impacts on these rights. ${ }^{9}$ Similarly, it has become an established legal principle in Canada that government decisions (such as licenses for new development projects) are at risk of nullification by courts if the state duty to consult has not been properly executed. ${ }^{10}$

In relation to these international debates, Sweden offers a particularly timely case to learn about how the implementation of the state duty to consult indigenous communities is unfolding in practice, being at a crucial juncture in Sami politics. In September 2017, the Swedish government launched its proposal for a bill on the duty to consult the Sami people. ${ }^{11}$ Intended by the state to become the first legally enshrined duty to consult with the Sami people in accordance with Sweden's international obligations, this proposal has attracted considerable debate. ${ }^{12}$ In their commentaries, several corporations and their branch organizations found it overly progressive, creating new regulatory uncertainties and threatening industry interests. Sami organizations and indigenous rights lawyers, in contrast, found it wanting - amongst other things, arguing that it lacked proper recognition of Sami material rights to property and culture and provided insufficient opportunities to meaningfully influence decisions. Although opinions were mixed, several Sami organizations in fact rejected it altogether. ${ }^{13}$ At the time of writing, the fate of the proposal is uncertain: the government ultimately proved unable to reach agreement between its ministries and finalize the proposal for legislative action in parliament before the September 2018 general elections. It remains to be seen how, if at all, a new government will progress with the draft proposal and various submissions from concerned parties.

In this paper, what interests us the most, is the assumption espoused by the government in conjunction with the proposed bill, that state authorities are already fully equipped to enact a new duty to consult. The government defends this view with reference to the fact that, as we outline further below, Swedish legislation already sets out duties to provide indigenous Sami communities with access to effective participation, with the interlinked assumption that state authorities thus must be aware of and able to implement such duties. For instance, the proposal suggests, in its impact assessment, that "affected government agencies generally have established procedures in place for consulting Sami representatives". ${ }^{14}$ A similar assumption underpins the government's recently proposed revision of the ethnic minority law, namely that during implementation "it can be assumed that public actors...have general awareness of existing legislation... and [will only face] minor uncertainties in defining further actions prompted by new legislation". ${ }^{15}$

We argue, in contrast, that such claims resonate poorly with existing knowledge of implementation failures on Sami procedural rights. Swedish Sápmi (the customary lands of the Sami now located within the nation state of Sweden) is characterized by a high degree of conflict over land and resource decisions, with growing number of court challenges and protests from Sami communities. ${ }^{16}$ This situation is 
conditioned by a general tendency in Swedish natural resource policies to delegate responsibility for engaging Sami communities (in so-called 'samråd' or corporate consultations) to developers. Meanwhile, sectoral legislation in the most important resource sectors, such as mining, forestry, and wind power operations, remains silent on the duty of the state to engage in direct consultation with the Sami people. ${ }^{17}$ Indeed, Sweden has received widespread and repeated criticism from international bodies for its failure to comply with obligations to protect Sami rights, including but not limited to the issue of effective procedures to ensure Sami influence in land and resource decisions on traditional lands. ${ }^{18}$ As noted above, such criticism was, in fact, a main motivation for the government to launch its proposal for the bill on a duty to consult. ${ }^{19}$

In connection with our earlier work we received indications that many state officials, contrary to the official government position, are, in fact, fully aware of this implementation gap. ${ }^{20}$ Thus motivated, our task in this paper is to explore the actual ability of Swedish state actors to enact the duty to consult, as perceived by the individual state officials and affected Sami communities. Without an accurate understanding of the current state of affairs, and knowledge of key issues to be addressed, it is impossible to know whether the proposed bill (whether in its original form or in some potential future, revised form) will lead to the expected outcomes. We structure our argument around one broad research question: How do Sami communities and state officials perceive the prerequisites for enacting the state duty to consult Sami communities in relation to natural resource developments? In other words, what are the key issues standing in the way of successful implementation? To address this question, we present novel empirical material, collating views from Sami communities and state officials in the key ministries and agencies working on land use issues.

Since a specific national law outlining the duty to consult the Sami people in accordance with international indigenous rights law is not yet in place in Sweden, the way we go about answering our question is by means of a "proxy". As alluded to above and as we outline in detail below (section 3), a state duty to provide opportunities for the Sami to effectively participate in land and resource decisions is, in fact, already enshrined in Swedish law. While it is often ignored, since 2009 the law on ethnic minorities (law 2009:724) has set out a state duty to promote the possibility for the Sami to maintain and develop their culture and ensure Sami communities' effective participation in decision making when decisions concern them.

Evidently, this duty is rooted in national minority law, which read alone does not clearly show the full register of indigenous rights, e.g. Sami rights to land and resources. ${ }^{21}$ Yet, as we outline below, and in line with expert opinion, the minority law should, in fact, be interpreted broadly in view of and in conformity with Sweden's obligations towards the Sami as an indigenous people, including Sami rights to traditional lands. While the Swedish state thus far has largely failed to apply the minority law in such a way as to give the intended protection for traditional Sami lands or the opportunity for the Sami to influence the use of such lands, the lessons from its 


\section{Rasmus Kløcker Larsen E Kaisa Raitio}

implementation are highly relevant in light of the proposed bill on a duty to consult. That is, in preparing for a new duty, we should examine what we can learn from the (lack of) implementation of an already existing duty.

\section{Material and Method}

The primary source of data for this paper is a two-day workshop convened 4-5 May 2017 , in a process that took about one year to plan, execute, and analyze. The study grew out of a long-term process of participatory action research with a range of partners among Sami communities and in collaboration with state agencies, fostering a process of reflection on shared as well as diverging perspectives on land use planning. ${ }^{22}$ We have elsewhere reflected at length on the theoretical and methodological underpinnings of designing such a critical collaborative dialogue between state and indigenous Sami actors; our focus here is on substantial findings. ${ }^{23}$ The central question posed in the workshop was how state agencies tasked with land use planning and licensing of resource developments on traditional Sami lands in Sweden can enact their duties, i.e. to promote reindeer herding as a central part of Sami culture and provide opportunities for Sami communities to effectively participate in land and resource decisions. In so doing, we sought to unpack what, in fact, this legal duty means in terms of everyday practice, and the enabling/disabling conditions for its implementation.

An essential design principle of the workshop was to bring the Sami communities and state officials together. Following international norms of indigenous selfdetermination (see further discussion below in section 3), this approach allowed Sami communities themselves to define the conditions under which Sami culture is to be meaningfully promoted. The state authorities, in turn, had the chance to identify the factors affect their ability to provide these conditions. ${ }^{24}$ Another important design principle was to invite two legal experts to explain the legal duties and answer questions of a legal nature: Marie B. Hagsgård, Swedish expert on the Advisory Committee for the European Framework Convention for the Protection of National Minorities, and Debbie Chan, Legal Counsel, Indigenous Legal Relations, British Columbia Ministry of Attorney General. British Columbia was chosen as a relevant counter-example that could inspire new thinking on the topic since, contrary to Sweden, it has had a well-established consultation procedure in place since $2010 . .^{25}$

In total, 34 people participated in the workshop, including the researchers and the two legal experts (Table 1). Participants received prior information that their contributions would be used in our research, ascribing contributions to the participating organizations, but not individuals. A workshop report, summarizing the process and results, was shared with participants with an invitation to comment and suggest corrections. ${ }^{26}$ Following the workshop, the results were also presented to the Swedish government's inter-ministerial commission on Sami policy, following an invitation from the Ministry of Culture. 
Table 1. Participants at the workshop (excluding researchers and facilitators).

\begin{tabular}{lc}
\hline Organization & No. of individuals \\
\hline Swedish Sami Association and six Sami communities & 9 \\
Sami Parliament & 2 \\
Ministry of Culture & 1 \\
Ministry of Enterprise and Innovation & 3 \\
County Administrative Board of Norrbotten & 2 \\
County Administrative Board of Västernorrland & 2 \\
Environmental Protection Agency & 3 \\
Energy Agency & 1 \\
Forestry Agency & 1 \\
Mineral Inspectorate & 1 \\
Total & 25 \\
\hline
\end{tabular}

\section{The Duty to Promote Conditions for the Sami to Maintain and Develop their Culture and to Ensure Effective Participation}

Since 2010, the Swedish Constitution (Ch. 1 \$2 constitution act 2010:1408) has recognized the duty of the state to promote opportunities for the Sami as an indigenous people to maintain and develop their culture and ways of life. The law on national minorities (law 2009:724) sets out the more specific state duty to actively promote conditions necessary for the Sami to maintain and develop their culture and to provide opportunities for effective participation in decision making when decisions concern questions that are important to them. Both the 2010 amendment to the Constitution and the law on national minorities $₫ 4$ (duty to promote the conditions for Sami to maintain and develop their culture) and $\$ 5$ (duty to provide opportunities for effective participation of the Sami) were phrased with the explicit intention of giving effect to the European Framework Convention for the Protection of National Minorities (specifically articles. 5 and 15). ${ }^{27}$

Since the Sami are not only a national minority, but also an indigenous people, all decisions that concern the use of their traditional land should be considered of importance to them when implementing the law on national minorities. However, the Swedish government has so far chosen not to be clear as to how the rights evoked in the Constitution and the minority law apply to land and resources. Instead, the government has focused on the application of the minority law exclusively in matters such as education and language. ${ }^{28}$ Arguably, this has further provoked a divide between government sectors, undermining the possibility for the minority law to concretely guide the ministries and agencies concerned with resource exploitation. However, legal interpretations by the European Expert Committee clearly explain that the duty to ensure effective participation for the Sami people under national 


\section{Rasmus Kløcker Larsen E Kaisa Raitio}

minority law should, in fact, be interpreted in view of and in conformity with Sweden's obligations towards the Sami as an indigenous people. ${ }^{29}$ The Advisory Committee has among other things stated that for all minorities that are indigenous peoples the use of their traditional land is at the heart of their culture: "representatives of [indigenous peoples] should therefore be closely involved in any decision-making on land rights and land usage in their traditional areas of residency". ${ }^{30}$ Significantly, the September 2018 recommendations from the Council of Europe showed that European political leaders share this view, i.e. that further actions by Sweden to implement the national minority law must explicitly consider Sami culture as encompassing rights to land and resources. ${ }^{31}$

Reindeer herding is a central part of Sami culture, and state agencies with a mandate to make land and resource decisions on reindeer herding lands must, according to the legislation referred to above and legal interpretation, thereby ensure that Sami reindeer herding communities (sameby, henceforth simply 'Sami communities') can effectively influence their decisions. This possibility for Sami communities to influence decisions affecting their traditional lands is one important way for state authorities to promote the possibility for the Sami to maintain and develop their culture. ${ }^{32}$ Based on traditional uses of land and resources, Swedish courts have recognized that Sami communities have property rights, particularly reindeer herding rights but also fishing and hunting rights. ${ }^{33}$ While user rights extend over all Sápmi, for historic reasons reindeer herding rights are seen as particularly strong on crown lands in the high mountains in Sweden, where reindeer herding has specific protection against other land uses (above the so-called "cultivation border" and on the "reindeer grazing mountains"). ${ }^{34}$ However, thus far, government agencies or courts have not interpreted this protection to mean that reindeer herding rights are prioritized above development projects, such as wind power operations or mineral exploitation, or that affected Sami communities are entitled to compensation for infringements in these situations. In addition to affected Sami communities, state agencies must also consider the need to consult the Sami Parliament (since it formally represents the public interests of the Sami people) and potentially affected Sami civil society associations. ${ }^{35}$

The duty of the Swedish state to provide opportunities for effective participation ( $\$ 5$ in the minority law) is, like the duty to consult and participatory rights more generally, procedural in nature. Consultation (in the minority law expressed as the "possibility to exert influence") here offers a mechanism for state agencies to ascertain if they are duly promoting conditions for the Sami to maintain and develop their culture by providing Sami communities with opportunities to effectively influence state decisions and define what actions are needed to promote their culture. ${ }^{36}$ It should be noted, though, that the part of the duty that demands the promotion of Sami culture ( $\$ 4$ in the minority law) is, in fact, a substantive commitment requiring positive state action. That is, irrespective of what procedures the government applies, it still has a duty to clarify potential impacts and avoid significant harm on substantive Sami 
rights to land and resources. This may require governments to reject proposals for resource developments altogether if they would result in significant cultural harm and/or to seek to reach agreements on licensing through various accommodation measures (including mitigation and compensation). ${ }^{37}$

In Sweden, the interpretation of what degree of influence affected indigenous communities must have on state decisions, i.e. what "effective participation" means in different situations, remains ambiguous. For instance, at present, there has been no clarification through law or court rulings of what degree of influence is acceptable under different conditions, or the situations in which the duty to ensure effective participation implies a duty to ensure actual Sami consent. Looking to European law, the European Framework Convention for the Protection of National Minorities (art. 15) only states that: "State Parties [must] ensure that [indigenous communities'] participation has a substantial influence... and that there is, as far as possible, a shared ownership of the decisions taken" (ACFC/31DOC(2008)001, point 19) (emphasis added). Likewise, a rule of nullification based on failed execution of the duty to ensure effective participation does not yet exist in Swedish law (nor, to our knowledge, in any other European Union member states).

\section{Results and Analysis: Enacting State Duties}

In this section, we present the substantial findings from the workshop described above (section 2). The purpose is to show how Sami communities and state officials in the key ministries and agencies in resource sectors view their legal duty, what this means concretely in terms of their everyday practice and the enabling/disabling conditions they identified regarding implementation. When relevant, we also connect key arguments based on the empirical evidence to theory based on secondary sources. The section is structured in three parts, showing how barriers and opportunities identified by Sami communities and state officials are not confined to any single level of governance but exist across scales. That is, they range from issues linked to everyday practice (sub-section 4.1: knowledge and routines and the resources to make improvements on these) over regulatory concerns (sub-section 4.2: sectoral legislation, institutions and coordination) to deeper political discourses (sub-section 4.3: politically framed ideas of "win-win" and "co-existence").

\subsection{Knowledge, routines and resources}

A main finding regards widespread uncertainty among state officials as to the concrete meaning of the duties placed upon them, including a perceived lack of knowledge, competence and routines. As one official stated: "Everyone at our agency needs to know more about indigenous rights". State officials expressed an urgent need to ensure long-term staffing of personnel with expertise in Sami culture and reindeer herding and competence development, including both the induction of new recruits and further education and training. Officials elaborated on how issues of staffing and 


\section{Rasmus Kløcker Larsen E Kaisa Raitio}

competence gaps mean that government institutions often lack basic knowledge of reindeer herding to be able to meaningfully engage with the Sami communities in an assessment of impacts of other land uses and resource projects. Knowledge gaps also relate to what the duty to ensure effective participation entails in practice. These messages from the Sami communities and state officials offer a strikingly different view of reality compared to the view presented in recent policy documents, which deny the existence of any substantial capacity gaps. In other words, in many cases, staff within public authorities do not, in their own opinion have the basic capacity to implement their duties because they do not know what is expected of them; they are unaware of Sami cultural practices and how they are affected by other land uses; and they do not have the routines and resources in place to carry out expected actions.

Besides competence development, several officials expressed an interest in negotiating so-called 'consultation check lists' in conjunction with Sami communities, i.e. guidance documents to clarify what constitutes mutually agreed processes for consultation in the context of their different sectors. For instance, the County Boards concluded in their working group on the second day that they had a need for "a checklist [outlining the procedures for how Sami actors want to be consulted] ... developed with Sami communities and the Sami Parliament". In a similar vein, the recent evaluation of the law on ethnic minorities pointed to the fact that representatives of both national minorities and local state authorities have called for clearer guidelines as to how to provide opportunities for effective participation. ${ }^{38}$ Such further guidance could build on and concretize already-existing recommendations, such as the guidelines issued by the UN Development Group. ${ }^{39}$

Taken together, one overarching message from the public authorities was that many aspects of practice can thus be improved within the existing regulatory framework if adequate resources are provided. While consultation checklists are an example of new routines that could be relatively easily developed, the necessary competence development identified by the civil servants cannot be achieved within the existing budgetary constraints. The proposed bill for a duty to consult can in this regard be perceived as problematic, since it assumes that state authorities will not need any significant additional resources for implementation, and does not recommend any further resources for this purpose. The voices of state officials stand in stark contrast to this view, pointing to already existing problems caused by an increased 'projectification' of their work, which has led to the disappearance of permanent staff with knowledge of Sami culture and reindeer herding and with long-standing relationships with and knowledge of Sami communities. As one official commented, "[agencies] have experienced a loss of resources, but the government still expects things to happen...".

The issue of a lack of resources was viewed as equally, or even more critical by the Sami communities. They were unequivocal in their call for the state to step up financial support to the Swedish Sami Association and individual Sami communities, so that they could effectively and equitably participate in the existing or envisioned 
modes of consultation. Today, Sami communities are often-times swamped in administrative tasks and requests from government agencies and developers to participate in meetings concerning new resource decisions that nonetheless provide very limited opportunities to influence decisions.

A major insight from the discussion was thus that providing Sami communities with adequate resources is in the direct interest of state agencies. In the words of one Sami participant: "To implement your duties, you need us to help you". This view is equally supported by both state officials and Sami representatives in our earlier studies. ${ }^{40}$ Indeed, the Advisory Committee for the Framework convention for the protection of national minorities has also highlighted the importance of economic investments to ensure that indigenous peoples such as the Sami may prepare for meaningful consultations. ${ }^{41}$ Another Sami community representative explained why this is the case: "Technical measures provided by developers will never ensure the promotion of Sami culture - the solutions must come from Sami communities themselves". In sum, additional resources were considered a prerequisite if Sami communities were to support state officials in fulfilling their duties.

\subsection{Sectoral legislation, institutions and coordination}

A major concern for both Sami communities and state officials regards the barriers at an institutional level in natural resource governance. Most participants advocated a shift from today's sectoral approach with decisions made one project at a time to a more holistic and landscape-based approach to land use planning and resource decisions. Indeed, it is well known how Sami rights are generally poorly protected, if at all, in land use planning and in the licensing of development projects. Among other things, this is the result of a "slicing and dicing" of issues concerning Sami rights into single industry projects and a widespread failure to account for the cumulative social and cultural impacts on Sami culture and rights. ${ }^{42}$

The failure to recognize Sami rights in land use planning and licensing has the direct effect of undermining state officials' ability to enact their duties to ensure Sami communities' effective participation. For instance, the permitting process for a wind farm is fragmented into separate permits for the wind farm itself, the related gravel pit, roads, and power corridors etc. This fragmentation makes it difficult, if not impossible, for the affected Sami communities - and the responsible state officials to grasp the full picture in terms of the impacts of the proposed project, not to mention the cumulative effects of the proposed project in combination with already existing developments. This, in turn, hampers their ability to make informed judgements. ${ }^{43}$ To address such challenges, one proposal that garnered much support was for the government to appoint a single coordinating government body to issue guidance documents, and to instruct and follow-up on enactment of duties by all sectoral agencies in order to ensure policy coherence as regards the duty to ensure effective participation. 


\section{Rasmus Kløcker Larsen Eూ Kaisa Raitio}

More fundamentally, however, sectoral legislation often-times comprises a stumbling block for state officials in enacting their duty to ensure Sami communities' effective participation. The Mineral Inspectorate, for instance, was struggling to identify any maneuvering space to ensure effective participation for Sami communities within the Minerals Act (law no. 1991:45): "We can do nothing... the duty [to consult during mineral concession permitting] is on the County Boards". In turn, it was apparent that the County Boards commonly look only to Environmental Code (law no 1998:808) requirements to ensure that developers hold meetings to exchange information with Sami communities (corporate consultations, or 'samråd') while carrying out the environmental impact assessments. Meanwhile, it is well known that the quality of the meetings held by developers with the Sami communities commonly leave much to be desired regarding the requirement of effective participation with little possibility for the Sami to actually influence decisions made by state authorities (see section 1 ). As one Sami community chairperson stated: "I've been to numerous meetings but have never been listened to. [Samråd] has become a word of abuse!".

The emerging picture is multilayered and complex: First, sectoral legislation does not refer to the existing duty to ensure Sami communities' effective participation in line with the national minority law (nor the duty to consult in conformity with Sweden's obligations towards the Sami as an indigenous people). Second, state officials and agencies are generally more committed to sectoral legislation than to their duty to promote the possibility for the Sami to maintain and develop their culture by ensuring Sami communities' effective participation. The result is that general state duties, rooted in the Constitution and in international law, and set out explicitly in the law on ethnic minorities, are not applied by state agencies in the intended way when contested land and resource decisions are made.

A key finding is thus about how, as Elinor Ostrom has aptly observed for other natural resource management situations, the actual rules of practice differ from the presumed rules of law. ${ }^{44}$ The general legal principle is namely that state agencies should apply the law in conformity with Sweden's international treaty obligations. ${ }^{45}$ However, today, state officials in several state agencies are clearly unaware of their existing duty based on the minority law or what it entails in practice. As such, they are prone to fail to ensure the right of the Sami to effective participation in land and resource decisions on Sami traditional lands.

\subsection{Political discourses: "co-existence", "win-win" and Sami communities as "stakeholders"}

Several political discourses prove to play a significant role in shaping the way state officials interpret sectoral legislation and opt to enact or ignore their duty towards the Sami. During the workshop it came to the fore how discourse centered on the concept of "co-existence" between Sami reindeer herding and development projects 
severely constrains the ability of state officials to enact their duty. This discourse, dominant in the Swedish debate concerning conflicts between Sami communities and competing land uses, emphasizes the possibility of "win-win" situations in which reindeer herding and the proposed new development projects can co-exist through adoption of mitigation measures. That is, the notion of co-existence is evoked by politicians and developers alike to propagate what is effectively a myth that Sami reindeer herding is inherently and endlessly "adaptable", and hence not significantly impacted by developments, i.e. it can "co-exist" with rapidly expanding mining, hydropower and wind power operations on Sami traditional lands. ${ }^{46}$

In so doing, government agencies are prone to ignore the hard reality that "winlose" situations are frequent when resources and land are limited. For instance, one state official explained how the assumption that Sami reindeer herding can co-exist with large development projects permeates the culture in agencies, reacting that "it is naive to believe that co-existence is possible. There're limits [to exploitation] and real conflicts of interest exist". Similarly, one Sami participant elaborated on how the discourse on co-existence is meaningless to Sami communities that are struggling for their very survival: "we've stopped talking about co-existence. For us, it's about being able to even exist." However, even though individual state officials may recognize the "win-lose" character of resource decisions, the dominance of the "win-win" discourse within their own agencies inhibit them from acting on such observations. In glossing over the substantive conflicts of interest, permit decisions often fail to transparently account for potential negative impacts of proposed resource developments and the trade-offs agencies make between the rights of the Sami and the interests of developers, in turn undermining the possibility for Sami communities to appeal licensing decisions.

Many participants saw the need for revisions in sectoral legislation and government procedures if conflicts of interest should be addressed more openly and transparently. This would involve, among other things: enforcing the rule that the burden of proof should be with the developer (currently frequently ignored); ${ }^{47}$ defining thresholds for the determination of significant harm on Sami rights to practice their culture (currently absent in Sweden); ${ }^{48}$ and recognizing that reindeer herding - like any other human activity - should be able not just to survive and adapt but also to develop and flourish. Such "development objectives", formulated by Sami communities themselves, could help place reindeer herding on par with other land uses, such as renewable energy and mineral extraction, when decisions are made.

Another limiting discourse concerned the way the Sami people and Sami organizations are conceived as "stakeholders" instead of rights-holders. This is important since, by ignoring Sami rights to land and resources, the possibility for constructive intercultural relations aimed at genuine reconciliation between the majority society and the indigenous Sami society will, then, also be limited. In other words, the stakeholder discourse risks leading government agencies to treat reindeer herding as one land user among many, failing to see reindeer herders' unique position as 


\section{Rasmus Kløcker Larsen Eూ Kaisa Raitio}

rights holders when making land use decisions. One example from the workshop concerning the lack of resources serves to substantiate this argument (see section 4.1): During the conversations about the problems of economic resources faced by the Sami communities, the a participant from the Ministry of Enterprise and Innovation explained why it had so far been unable to provide the long-term funding requested: "The Swedish Sami Association is an interest organization and then special guidelines apply". By branding the Sami Association as any other kind of interest organization (i.e. in line with regular Swedish civil society organizations) its legitimate role as a representative body for Sami reindeer herding communities as indigenous rightsholders is ignored. This means that the state is deflecting its obligation to engage consistently with Sami rights. ${ }^{49}$ Indeed, it is well known how, to date, the Swedish state has insisted on the Sami Parliament being the sole representative body for the Sami people. ${ }^{50}$ The weak role of the Swedish Sami Association and Sami communities in the proposed bill for a duty to consult was also, in fact, a core point of contention in many submissions from Sami actors and legal scholars, and highlights the need for the state to pay more attention to the Sami communities as rights-holding subjects.

\section{Conclusions}

At this critical juncture where Sweden is preparing to legislate a duty to consult the Sami people, with the express aim of meeting its international treaty obligations in a more consistent manner, this paper has considered the lessons learned from the implementation of existing state duty. The duty that we have examined, as a "proxy", is the duty set out in the minority law to promote the possibility for the Sami to maintain and develop their culture and to ensure Sami communities' effective participation in land and resource decisions. Contrary to popular assumption, or at least the publicly espoused assumptions in government policy, we have here demonstrated the existence of considerable implementation failures.

In so doing, to our knowledge, this paper offers the first empirical assessment of the views of indigenous communities and state officials themselves on the prospect of enacting the state duty to consult indigenous communities (or ensure their effective participation in decision making). Whereas policy debates have moved rapidly to encourage consultations between indigenous communities, states and developers in the context of natural resource developments, very little research has yet explored the concrete potential and the enabling/disabling conditions of such procedures and practices. Generally, scholarly work has tended to focus on comprehensive settlements (land claims, treaties) rather than the development and implementation of consultation processes. Notable examples of this research into territorial solutions include Canada's landmark approach to modern treaties and Aboriginal Australians' struggle for native title, e.g. linked to the high court Mabo decision of $1992 .{ }^{51}$ Similarly, intercultural dialogue has historically received scant attention in the study of 
resource negotiations. ${ }^{52}$ To the extent available, such research has tended to focus on the agency of indigenous or corporate actors, including community-led planning and impact assessments and impact-benefit agreements in direct negotiation between communities and developers..$^{53}$ Meanwhile, limited attention has been paid to the perspectives and agency of state officials. Arguably, such knowledge has highly significant societal relevance, shedding light on whether recent policy reforms are set to meet stated objectives to protect indigenous rights and sustainably manage natural resources.

What then can be learned from these experiences as the state embarks upon a new duty to consult the Sami people? Given past implementation failures, one key issue is arguably whether officials or court judges will be given the teeth to enforce new consultation rules and whether Sami communities will be able to hold the government accountable if it fails to enact its new duty. If not, there is an obvious risk that well-intentioned reform will result in seemingly rapid improvement on paper, but is quickly subsumed by knowledge and capacity gaps in state institutions and (real and/or imagined) conflicts with sectoral legislation. Mechanisms of appeal and/or rules of nullification can, in this regard, play an important role.

It is worth noting here that considerations regarding the need to clarify the degree of influence on decisions (as addressed in the sliding scale theory) and the potential need for a rule of nullification were, in fact, both touched upon in conjunction with the recent update to Sweden's law on ethnic minorities and in the proposed bill on a consultation duty. ${ }^{54}$ In its recent recommendations, the Council of Europe also highlighted the need to introduce effective remedy in case of non-compliance. However, no new means of remedy have been incorporated by the government into the proposed legislative changes, neither for the law on national minorities, nor for the proposed consultation duty. As noted, to comply with their duty, and indeed to ensure any practical relevance for indigenous peoples, state agencies must ensure that Sami communities have a real influence on land and resource decisions. The decision to exclude principles that could have helped clarify the duty and allow for holding government agencies to account if they fail to enact their duty are thus likely to significantly reduce the effect of the duties in practice in the future.

Another key argument to arise from the findings is that it would significantly aid implementation if sectoral laws such as the Forestry Act, the Minerals Act, and the Environmental Code were amended to consistently refer to the requirement to enact state duties toward the Sami (as noted sectoral laws are currently silent on the state duty to consult or ensure effective Sami participation). One possibility would be to insert, in the sectoral laws, adequate references to the minority law and/or a potential new bill on a consultation duty, clarifying when and how the state agencies must give effect to these duties. It is worth mentioning that the government, in its recent review of how the implementation of the minority law could be strengthened, found that changes were required in laws in other sectors than resource development, such as the school law (law 2010:800), to clarify and detail the state duty to ensure effective 


\section{Rasmus Kløcker Larsen E Kaisa Raitio}

participation for minorities. ${ }^{55}$ One can wonder whether this principle of updating across sectoral laws should also apply to resource sectors as an essential means of giving effect to Sami indigenous rights.

Despite these structural constraints, however, we have also seen that much, in fact, could be gained in the near-term if state officials were supported in more proactively interpreting and navigating their room for maneuver within existing sectoral legislation. This would require the state to step up investment into resources, competence development, and staffing as well as the development (together with Sami communities) of new routines and guidelines for consultation, in accordance with international law. The great need for such investment should not discourage government, on the contrary it is emblematic of why this effort is so urgently needed in the first place.

Taking a step back and reflecting on the wider theoretical implications of the findings, it is noteworthy that the barriers and opportunities identified by Sami communities and state officials were not confined to any single level of governance but existed across scales. This observation resonates with wider scholarship in indigenous geographies and critical studies of extractivism that have articulated how indigenous peoples must exert struggles for their rights in multiple forums and across institutional scales. ${ }^{56}$ Indeed, often-times, indigenous peoples must - if they are to see meaningful change -"scale up" resistance to resource developments from projectby-project decisions to debate around systemic and nation-wide solutions. ${ }^{57}$

The point here is that, when aiming to enact state duties towards indigenous peoples, the "scaling" of the policy problem (i.e. the definition of the severity of the implementation gap and its potential range of solutions) must be relevant to the indigenous peoples themselves. This demonstrates how a robust understanding of governance of natural resources on indigenous lands requires a multi-perspectival and cross-scalar analysis. Arguably, research such as that delivered in this paper, has an important role in eliciting perspectives from indigenous communities and state officials themselves on the intractable policy issues they face. To be sure, indigenous research methodologies have helped re-center indigenous perspectives on resource issues, and while much work remains to be done, progress is also being made in Swedish Sápmi. ${ }^{58}$ Building on such scholarship, we contend that more work remains to be done in line with the ambition of this paper, namely inquiring about the perspectives of both indigenous communities and their counterparts in resource negotiations, such as state officials.

On a final note, and perhaps surprisingly, our results demonstrate a relatively high degree of convergence in the views of the participating state officials and Sami communities. The "street-level bureaucrats" 59 that joined the workshop were generally already aware of the lack of knowledge and skills in their organizations and could express these insights when allowed to deliberate upon the situation in a safe space disconnected from individual resource decisions. This observation challenges the common view in much research and public debate, namely that, when opinions 
about the efficacy of public policy diverge, then the divide is between the state as a whole and indigenous representatives.

Rather, as shown in this study, the most significant divide seems to exist within the state apparatus, i.e. between the national political leadership (or at least its official position), and street-level state officials faced with the consequences of implementation failure in their daily work, e.g. in the form of prolonged permit processes and escalated conflicts. ${ }^{60}$ As observed by Funder and Marani, street-level bureaucrats in natural resource governance tend to "occupy an ambiguous position in which they are expected to implement lofty laws and policies with limited means and in a complex local reality". ${ }^{61}$ Yet, problem definitions - and hence the "scaling" of the policy issues - are typically filtered politically by central state executives and politicians in a dynamic prone to create a mismatch with local realities. Our closing argument must thus be in favor of national government making better use of an important source of knowledge when it seeks to improve the enactment of state duties: its own officials with deep insights from their complex realities across resource sectors and within the different parts of Swedish Sápmi.

\section{Acknowledgements}

This study was funded by the Swedish Environmental Protection Agency through the project "Contested landscapes: navigating competing claims on cumulative impacts (CO-LAND)" (NV-03501-15) with co-funding from Research Council Formas through the project "Indigenous Rights and the Global Politics of Resource Extraction: The Case of Mining in Sápmi” (211.2012-135) and the Swedish University of Agricultural Sciences (SLU) through the project "Impacts and Rights". We are indebted to Marie B. Hagsgård (Member of the Advisory Committee for the European Framework Convention for the Protection of National Minorities) and Debbie Chan (Legal Counsel, Indigenous Legal Relations, British Columbia Ministry of Attorney General) for their generous advice during this study and comments on drafts of this paper. We also thank Rebecca Lawrence (Stockholm University), Leena Heinämäki (University of Lapland) and Christina Allard (Luleå University of Technology) for helpful comments and advice, and Carl Österlin (Stockholm University) for his support in the workshop that generated the primary data. Any remaining errors are naturally the responsibility of the authors alone.

\section{Notes}

1. Christina Allard, "The Rationale for the Duty to Consult Indigenous Peoples: Comparative Reflections from Nordic and Canadian Legal Contexts", Arctic Review on Law and Politics 9 (2018): 25-43.

2. Matthias Åhrén, Indigenous peoples'status in the international legal system (Oxford: University Press, 2016): pages 202ff. 


\section{Rasmus Kløcker Larsen E Kaisa Raitio}

3. Tara Ward, “The Right to Free, Prior, and Informed Consent: Indigenous Peoples' Participation Rights within International Law", Northwestern fournal of International Human Rights (2011): 54-84.

4. James Anaya, Report of the Special Rapporteur on the situation of human rights and fundamental freedoms of indigenous people, United Nations Human Rights Council (A/HRC/12/34, 2009).

5. SeePoma Poma v. Peru, Communication No. 1457/2006/UNDoc.CCPR/C/95/D/1457/2006, 27 March 2009; Inter-American Court of Human Rights, Saramaka People v. Suriname, Judgment of 28 November 2007, IACtHR Series C, No. 172, para. 134; African Commission on Human and Peoples Rights, Centre for Minority Rights Development (Kenya) and Minority Rights Group (on behalf of Endorois Welfare Council), Kenya, 27th Activity Report: Jun 2009 - Nov 2009 (2009), para. 291. See also Leena Heinämäki \& Dorothée Cambou, "New Proposal for the Nordic Sámi Convention: An Appraisal of the Sámi People's Right to Self-determination", Retfaerd 2 (2018, forthcoming): 11.

6. Rasmus Kløcker Larsen, "Impact assessment and indigenous self-determination: a scalar framework of participation options", Impact Assessment and Project Appraisal (2017), http:// dx.doi.org/10.1080/14615517.2017.1390874.

7. E.g. Tony Corbett and Ciaran O'Faircheallaigh, "Unmasking the Politics of Native Title: The National Native Title Tribunal's Application of the NTA's Arbitration Provisions", The University of Western Australia Law Review 33 (2006): 153-177.

8. Åhrén, 2016. Indigenous peoples'status, 2, page 139.

9. Government of British Columbia, Updated Procedures For Meeting Legal Obligations When Consulting First Nations", Province of British Columbia (2010), http://www2.gov.bc.ca/assets/ gov/environment/natural-resource-stewardship/consulting-with-first-nations/first-nations/ legal_obligations_when_consulting_with_first_nations.pdf.

10. Supreme Court of Canada in Clyde River (Hamlet) v. Petroleum Geo-Services Inc., 2017 SCC 40 at para. 24.

11. Government of Sweden, Konsultation $i$ frågor som rör det samiska folket, Ds 2017:43 (2017), https://www.regeringen.se/rattsliga-dokument/departementsserien-och-promemorior/2017/09/ds-201743/.

12. Ibid, pages $33 \mathrm{ff}$.

13. See the commentaries from e.g. the state-owned enterprises for forestry (Sveaskog) and hydro-power (Vattenfall) and the branch organization for the mining industry (SveMin), and from e.g. Swedish Sami Association (SSR) and the Sami Parliament, at: http://www.regeringen.se/remisser/2017/09/remiss-ds-201743-konsultation-i-fragor-som-ror-det-samiska-folket/ (accessed June 2017).

14. Government of Sweden, 2017. Konsultation, 11, page 85. That the term used by the government is "samråd". As explained later in the introduction, this refers to an existing practice that does not equate consultation as understood within international law.

15. Government of Sweden, Lagrådsremiss - En stärkt minoritetspolitik [Referral on a strengthened minority policy] (2018, page 76), https://www.regeringen.se/rattsliga-dokument/lagradsremiss/2018/02/en-starkt-minoritetspolitik/.

16. Kaisa Raitio and Rebecca Lawrence, "To engage or not to engage? Deliberation and activism on Sámi land rights in mining permitting", Conference paper, Nordic Geographers Meeting, Stockholm, Sweden, June 18-21 2017. 2017; Rebecca Lawrence, "Internal colonisation and indigenous resource sovereignty: wind power developments on traditional Saami lands", Environment and Planning D: Society and Space 32(6) (2014): 1036-1053.

17. Malin Brännstrom, Skogsbruk och renskötsel på samma mark: En rättsvetenskaplig studie av äganderätten och renskötselrätten (Umeå: University Press, 2017); Allard, 2018, The Rationale for the Duty to Consult, 3. 


\section{Implementing the State Duty to Consult in Land and Resource Decisions}

18. See e.g. the United Nations Committee on the Elimination of Racial Discrimination, Concluding observations on the combined twenty-second and twenty-third periodic reports of Sweden (CERD/C/SWE/CO/22-23). Renewed criticism was also provided by the Council of Europe on 12 Sept. 2018, see Resolution CM/Res(2018)9 on the implementation of the Framework Convention for the Protection of National Minorities by Sweden.

19. Government of Sweden, 2017. Konsultation, 2017, 11, pages 33ff. It should also be noted that another central motivation for the bill is that it is considered a prerequisite for Sweden to comply with the Nordic Sami Convention, which is currently being negotiated among the Nordic states and the three Sami Parliaments in Sweden, Norway and Finland.

20. Rasmus Kløcker Larsen et al., "Sami-State collaboration in the governance of cumulative effects assessment: a critical action research approach" Environmental Impact Assessment Review 64 (2017): 67-76.

21. See e.g. Allard, 2018, The Rationale for the Duty to Consult, 3.

22. For an introduction to the theory and methods underlying participatory action research please see: Davydd Greenwood and Morten Levin, Introduction to Action Research: Social Research for Social Change (London: Sage, 2007).

23. Rasmus Kløcker Larsen et al., 2017, Sami-State collaboration, 20.

24. Sami culture encompasses a vast range of practices (spiritual, hunting, fishing etc.), however the emphasis in this workshop was on reindeer herding and the Sami participants were hence the reindeer herding districts (in this text, simply 'Sami community'). The organizational form of Sami communities is a hybrid of colonial attempts to govern reindeer herding, combined with Sami social and cultural practices. See also Rebecca Lawrence and Matthias Åhrén, "Mining as colonisation: the need for restorative justice and restitution of traditional Sami lands", in Nature, Temporality and Environmental Management: Scandinavian and Australian Perspectives on Landscapes and Peoples, eds. Head, L., Saltzman, S., Setten, G., Stenseke, M. (London: Taylor and Francis, 2016), 149-166.

25. Government of British Columbia, 2010, Updated Procedures for Meeting Legal Obligations, 9.

26. The workshop report (in Swedish) is available here: Rasmus Kløcker Larsen and Kaisa Raitio, 2017. Hur kan myndigheter $i$ planerings- och tillståndsärenden främja renskötseln som en central del av samisk kultur och ge samiska företrädare möjlighet till inflytande? Workshop report, Sigtuna, 4-5 May 2017, https://mediamanager.sei.org/documents/Projects/Workshoprapport-Sigtuna-Slutversion-2017-10-06.pdf.

27. See e.g. Government of Sweden, 2009. En reformerad grundlag [a reformed constitution], prop. 2009/10:80.

28. The absence of attention to resource sectors or agencies tasked with the regulation of forestry, mining, and so forth is particularly evident in: Government of Sweden, 2017. Lagrådsremiss - En stärkt minoritetspolitik, 15, see particularly section 13.3 and page 94 .

29 See e.g. Fourth opinion on Sweden, 22 June 2017 of the Advisory Committee on the European Framework Convention for the protection of National Minorities pp. 102, 104 and 105.

30. Ibid. p. 37.

31. Resolution CM/Res (2018)9, 22. See specifically recommendation number 2 .

32. Hagsgård, Renskötselrätten och de allmänna intressena av samisk kultur och renskötsel $i$ nationalparker och naturreservat, Report to the Swedish Environmental Protection Agency (2016).

33. The Skattefjäll case (NJA 1981 s. 1); Christina Allard, Renskötselrätt i nordisk belysning (Gothenburg: Makadam, 2015); Christina Allard, "The Nordic countries' law on Sámi territorial rights", Arctic Review on Law and Politics 2 (2011): 159-183.

34. Reindeer Herding Act 1971, ss. 26, 30, 32; Prop. 1971:51, pp. 132-3; Bertil Bengtsson, Samerätt: En översikt (Stockholm: Norstedts Juridik, 2004): 62.

35. Hagsgård, Renskötselrätten och de allmänna intressena, 2016, 35. 


\section{Rasmus Kløcker Larsen E Kaisa Raitio}

36. The proposal for the bill on a consultation duty explicitly uses the notion of 'konsultation' instead of 'samrad' to designate the communication that must take place between government and the Sami people. This is intended to indicate the novelty of the duty. Please also recall that due to the different sources of law underpinning the duty to consult and the minority law, the meanings of "consultation" and "possibility to exert influence" are not necessarily synonymous.

37. On the options available to state agencies in terms of accommodation measures see Hagsgård, 2016. Renskötselrätten och de allmänna intressena, 35.

38. Government of Sweden 2017. Utvärdering av minoritetslagstiftningen [Evaluation of the law on ethnic minorities], SOU 2017:60, pp. 38-44 and 103-107.

39. See Hagsgård, 2016. Renskötselrätten och de allmänna intressena, 35. Such guidance covers, among other, the provision of information on the planned exploitation well in time before the decision so as to allow the indigenous people a chance to discuss and form an opinion, including a preliminary assessment from the state authority of the likely economic, social and cultural and environmental impact of the planned exploitation.

40. See e.g. Rasmus Kløcker Larsen et al., 2017, Sami-State collaboration, 20.

41. Forth opinion on Sweden, 22 June 2017 of the Advisory Committee on the European Framework Convention for the protection of National Minorities p. 104.

42. E.g. Rebecca Lawrence and Rasmus Kløcker Larsen, "The politics of planning: assessing the impacts of mining on Sami lands", Third World Quarterly 38(5) (2017): 1164-1180.

43. See also Rasmus Kløcker Larsen et al., 2017, Sami-State collaboration, 20.

44. Elinor Ostrom, Understanding institutional diversity (Princeton: University Press, 2005).

45. Ove Bring, Said Mahmoudi, Pål Wrange, Sverige och folkrätten (Stockholm: Norstedts Juridik, $20145^{\text {th }}$. ed), page 59. See also Hagsgård, 2016. Renskötselrätten och de allmänna intressena, 35.

46. For other critiques of the political discourse of co-existence see e.g. Anette Löf, "Challenging Adaptability. Analysing the Governance of Reindeer Herding in Sweden", University Press. Umeå (Doctoral dissertation, 2014); Lawrence and Kløcker Larsen, 2017. The politics of planning, 20.

47. The importance of the burden of proof is discussed in: Jan Darpö, "Karin och Susannes glädje, Lars-Anders sorg? Om uppdelade tillståndsprövningar på miljöområdet och respekten för samernas renskötselrätt”, Nordic Environmental Law fournal 2 (2016).

48. For a thorough discussion of the right to culture and the important of thresholds for significant harm see: See Lena Heinämäki et al. Saamelaisten oikeuksien toteutuminen: kansainvälinen oikeusvertaileva tutkimus [Actualizing Sámi Rights: International Comparative Research, in Finnish and in English], Publications of Prime Minister's Office, Finland, 2017.

49. For instance, according to Article 19 of the United Nations Declaration on the Rights of Indigenous Peoples states shall consult and cooperate in good faith with the indigenous peoples concerned through their own representative institutions in order to obtain their free, prior and informed consent before adopting and implementing legislative or administrative measures that may affect them.

50. Rebecca Lawrence and Ulf Mörkenstam, "Indigenous Self-Determination through a Government Agency? The Impossible Task of the Swedish Sámediggi (Sámi Parliament)", International Fourney of Minority and Group Rights 23:1 (2016): 105 - 127.

51. Benjamin J. Richardson et al., "Indigenous peoples and environmental management: a review of Canadian regional agreements and their potential application to Australia", Environmental and Planning Law 11(4) (1994): 320-343; Parry Agius et al., "Comprehensive native title negotiations in South Australia", in Honor among nations? Treaties and agreements with indigenous peoples, eds. Langton et al. (Melbourne: University Press, 2004), 203-219. 
52. Richard Howitt, "The other side of the table. Corporate culture and negotiating with resource companies", Regional Agreements Paper 3 (1997) (Acton: Australian Institute of Aboriginal and Torres Strait Islander Studies).

53. E.g. Lawrence and Larsen, 2017. Politics of planning, 47; Ciaran O'Faircheallaigh and Tony Corbett, "Indigenous participation in environmental management of mining projects: the role of negotiated agreements", Environmental Politics 4 (2005): 629-47.

54. Government of Sweden, 2017. Konsultation, 11.

55. En stärkt minoritetspolitik, 15 (e.g. page 98 ff).

56. E.g. Brad Coombes, Jay T. Johnson and Richard Howitt, "Indigenous geographies I: Mere resource conflicts? The complexities in indigenous land and environmental claims", Progress in Human Geography 36(6) (2012): 810-821; Burchardt, Hans-Jürgen Burchardt and Kristina Dietz, "(Neo-)extractivism - a new challenge for development theory from Latin America", Third World Quarterly 35(3) (2014): 468-486.

57. Agius et al 2004. Comprehensive native title negotiations, 51.

58. Anna-Lill Drugge, Ethics in indigenous research: past experiences - future challenges (Umeå: Vaartoe - Centre for Sami Research, 2016).

59. Michael Lipsky, Street-level bureaucracy - Dilemmas of the individual in public services (New York: Russell Sage Foundation, 2010).

60. See also Kløcker Larsen et al. 2017. Sami-State collaboration, 43.

61. Mikkel Funder and Martin Marani, "Local bureaucrats as bricoleurs. The everyday implementation practices of county environment officers in rural Kenya", International fournal of the Commons 9(1) (2015): 87-106, page 87. 